\title{
M\&A in het tijdperk van nationale beschermingsmechanismen: gaan we richting een Europese CFIUS?
}

\author{
Mr.L. Gasseling*
}

\begin{abstract}
Op 19 maart 2019 is de Screeningverordening aangenomen, waarmee een kader verschaft is voor coördinatie en samenwerking tussen lidstaten en de Europese Commissie ten aanzien van de screening van FDI. In dit artikel bespreekt de auteur investeringsscreening in de EU en VS, en of de Screeningverordening een stap is in de richting van een Europese CFIUS.
\end{abstract}

\section{Introductie}

Daar waar lange tijd juist het versoepelen van markttoegang voor buitenlandse investeringen wereldwijd hoog op de agenda stond, lijkt het tij anno 2020 gekeerd te zijn, met toegenomen protectionistisch beleid en hoogoplopende handelsconflicten tot gevolg. Deze trend hangt gedeeltelijk samen met de sterke toename van buitenlandse directe investeringen (ook wel foreign direct investment genoemd, hierna: FDI), deels gecoördineerd als onderdeel van overheidsstrategieën zoals China Manufacturing 2025. ${ }^{1}$ Het is begrijpelijk dat hier zorgen over zijn, aangezien investeringen gedaan worden in 'vitale' sectoren zoals energie, ICT/telecom, transport, chemie en defensie. $^{2}$ Buitenlandse invloed op of zeggenschap over vennootschappen in deze vitale sectoren (de 'vitale vennootschappen') kan de continuïteit van vitale sectoren, de integriteit en exclusiviteit van informatie en mogelijk zelfs het functioneren van de democratische rechtsorde in gevaar brengen. ${ }^{3}$

Om deze risico's te mitigeren heeft een groot aantal (EU-)landen inmiddels een screeningmechanisme ingevoerd op grond waarvan FDI gescreend kan worden. Ook in Nederland wordt momenteel aan een algemeen screeningmechanisme gewerkt. ${ }^{4}$ In grote lijnen zijn deze mechanismen vergelijk-

Mr. L. Gasseling is jurist Litigation \& Insolvency bij AKD te Rotterdam.

1. Zie hierover in detail: China manufacturing 2025: Putting industrial policy ahead of market forces, 2017.

2. E.J. Breukink \& C.D.J. Bulten, De bescherming van vitale vennootschappen, Ondernemingsrecht 2018/16, afl. 2, par. 3.2 .

3. Zie voor het begrip vitale vennootschap en de risico's die daaraan verbonden zijn: C.D.J. Bulten, B.J. de Jong, E.J. Breukink \& A. Jettinghoff, Vitale vennootschappen in veilige handen (VDHI nr. 142), Deventer: Wolters Kluwer 2017, p. 22-28.

4. Het kabinet verwacht eind 2020 te komen met een wetsvoorstel, zie de brief van de Ministers van Economische Zaken en Klimaat en Justitie en Veiligheid van 11 november 2019 (Kamerstukken II 2019/20, 30821, nr. 97), p. 7. baar: een investering die een gevaar is of kan zijn voor de openbare orde of nationale veiligheid van het ontvangende land kan worden teruggedraaid of geblokkeerd. Een Unierechtelijke aanpak ontbrak echter tot voor kort. Op 19 maart 2019 is Verordening (EU) 2019/452 tot vaststelling van een kader voor de screening van buitenlandse directe investeringen in de Unie (hierna: de Screeningverordening) aangenomen. Onder de Screeningverordening blijft de bevoegdheid tot het al dan niet aanhouden of instellen van een screeningmechanisme bij de individuele lidstaten liggen. Tegelijkertijd poogt de verordening investeerders meer rechtszekerheid te bieden en verschaft zij een kader voor coördinatie en samenwerking tussen de verschillende lidstaten en de Commissie. ${ }^{5}$

De Screeningverordening is daarmee veel beperkter van aard dan de Amerikaanse investeringsscreening door de 'Committee on Foreign Investments in the United States' (hierna: CFIUS). In de periode voorafgaand aan en na de invoering van de Screeningverordening is vaak de vergelijking met CFIUS gemaakt. In de aanloop naar de Screeningverordening werd door sommige auteurs zelfs een CFIUS-achtig systeem op Europees niveau verdedigd. ${ }^{6}$ Het is niet ondenkbaar dat de Screeningverordening een eerste (voorzichtige) stap is in de richting van een Europees algemeen screeningmechanisme, hoewel hiervoor nog enkele Unierechtelijke hordes genomen moeten worden (zie par. 4.2).

In dit artikel beschrijf ik allereerst de achtergrond, inhoud en tekortkomingen van de Screeningverordening (par. 2), waarna de investeringsscreening door CFIUS in de Verenigde Staten wordt weergegeven (par. 3). Tot slot ga ik in op de impact en toekomst van de Screeningverordening (par. 4), waarbij ik tot de conclusie kom dat de Screeningverordening geen stap is in de richting van een Europese CFIUS.

5. Overweging 7 Screeningverordening.

6. Zie o.m. F. Di Benedetto, Reciprocity in international trade and investment law and the establishment of a European committee on foreign investment, Il Diritto del Commercio Internazionale (31) 2017, p. 22-27, Safe and sound: An EU approach to sovereign investment, bruegel.org, p. 7-8 en J. Chaffin, Beijing warned on foreign investment, Financial Times 20 september 2011. De Commissie ziet de toegevoegde waarde (nog) niet, zie SWD(2017)297 final, p. 9. 


\section{Maandblad}

Ondernemingsrecht

\section{Screening van FDI in de Europese Unie}

\subsection{Achtergrond}

In vergelijking met haar handelspartners is de EU laat met het invoeren van wetgeving op het gebied van investeringsscreening. Dit hangt sterk samen met het feit dat individuele lidstaten de exclusieve bevoegdheid hebben over de bescherming van de nationale veiligheid (art. 4 Verdrag betreffende de Europese Unie; VEU). Bovendien streeft de EU juist naar een geleidelijke afschaffing van beperkingen voor het internationale handelsverkeer en buitenlandse directe investeringen (art. 206 Verdrag betreffende de werking van de Europese Unie; VWEU). Daarbij komt dat de EU een groot belang heeft bij het behouden van een open investeringsklimaat. Een open investeringsklimaat kan immers zorgen voor een influx aan kapitaal, innovatie en concurrentie, en kan bijdragen aan een betere allocatie van productiefactoren. ${ }^{7}$ De lidstaten van de EU zijn samen de grootste ontvanger van FDI ter wereld, met een totaal aan inkomende FDI van USD 277,6 miljard in $2018 .^{8}$

In dit artikel houd ik de definitie van FDI uit de Screeningverordening aan, waarin FDI ruim gedefinieerd is en niet enkel het aankopen van aandelen in een kapitaalvennootschap omvat. ${ }^{9}$ Het zal aan de lidstaten zijn om de definitie uit de Screeningverordening te concretiseren, door aan te geven wanneer sprake is van een investering die binnen de reikwijdte van een screeningmechanisme valt.

De huidige zorgen ten aanzien van FDI zijn geenszins nieuw. Sterker nog, de discussie omtrent het reguleren van FDI heeft zich omstreeks 2008 reeds voorgedaan, toen er zorgen waren over de sterke toename van investeringen door staatsfondsen zoals de Abu Dhabi Investment Authority en de Government of Singapore Investment Corporation. ${ }^{10}$ Lidstaten maakten zich destijds onder meer zorgen over het mogelijke aanwenden van de enorme vermogens voor politieke doeleinden, een verstoring van de mededinging en een mogelijke 'shopping spree' in vitale sectoren tijdens de financiële crisis, waardoor een afhankelijkheid ten opzichte van buitenlandse investeerders

7. Kamerstukken II 2007/08, 31350, nr. 1, p. 5-6, COM(2017)494 final, p. 4 en G.T.M.J. Raaijmakers \& J.J. Trommel, Staatsfondsen: test voor het ondernemingsrecht, Ondernemingsrecht 2005/157, afl. 15, par. 5.1.

8. UNCTAD, World investment report 2019, New York: UNCTAD 2019, p. 212. De OECD hanteert in haar onderzoeksrapporten een andere definitie van FDI dan de Screeningverordening. Zie voor deze definitie OECD, OECD benchmark definition of foreign direct investment, Parijs: OECD 2008.

9. Art. 2 onder 1 Screeningverordening. De Screeningverordening sluit met deze definitie aan bij rechtspraak van het Hof, zie HvJ EU 16 mei 2017, Advies 2/15, ECLI:EU:C:2017:376 (Vrijhandelsverdrag EUSingapore), par. 80.

10. Raaijmakers \& Trommel 2005, par. 3, The so-called 'Sovereign Wealth Funds': Regulatory issues, financial stability and prudential stability, ec.europa.eu, p. 15-17 en $\operatorname{COM}(2008) 115$ final, p. 3 . en mogendheden zou kunnen ontstaan. ${ }^{11}$ Hoewel er stemmen opgingen voor een CFIUS-achtig systeem op EU-niveau, werd er uiteindelijk voor gekozen om op internationaal niveau te streven naar 'best practices' voor staatsfondsen. ${ }^{12}$

Door de sterke toename van FDI vanuit China in sectoren die van vitaal belang zijn voor de openbare orde, de nationale veiligheid en industrieel beleid werd de bovenstaande discussie wederom aangezwengeld en nam de vraag naar een Europees screeningmechanisme toe. ${ }^{13}$ Verschillende lidstaten maakten zich zorgen over strategische investeringen in sectoren die samenhangen met de nationale veiligheid en industrieel beleid, waarbij enkele lidstaten zich eveneens stoorden aan het gebrek aan reciprociteit in handelsrelaties (vooral ten aanzien van China). ${ }^{14}$ Deze zorgen vonden gehoor bij zowel het Europees Parlement als de Commissie. ${ }^{15}$ Er werd een onderzoek aangekondigd naar FDI in vitale sectoren en enkele maanden later publiceerde de Commissie het eerste voorstel voor de Screeningverordening. ${ }^{16}$ De Screeningverordening is uiteindelijk op 19 maart 2019 gepubliceerd, slechts achttien maanden na het eerste voorstel.

\subsection{Relatie met het Unierecht}

De Screeningverordening is aangenomen onder de gemeenschappelijke handelspolitiek van de Unie (art. 207 VWEU), een exclusieve bevoegdheid van de EU (art. 3 lid 1 onder e VWEU). Het Europees Parlement en de Commissie zijn bevoegd verordeningen aan te nemen die het kader voor de uitvoering van de gemeenschappelijke handelspolitiek van de EU bepalen (art. 207 lid 2 VWEU). ${ }^{17}$

Nationale screeningmechanismen die ingevoerd zijn (of gaan worden) ten aanzien van derde landen moeten zowel aan de vereisten uit de Screeningverordening voldoen als aan de vereisten die voortvloeien uit het vrije verkeer van kapitaal (art. $63 \mathrm{VWEU}) .{ }^{18}$ In artikel $63 \mathrm{VWEU}$ staat dat alle beperkingen van het kapitaalverkeer tussen lidstaten onderling en tussen lidstaten en derde landen verboden zijn. Het is vaste recht-

11. J. Chaisse, The regulation of sovereign wealth funds in the European Union, in: K.P. Sauvant, L.E. Sachs \& W.P.F. Schmit Jongbloed (red.), Sovereign investment: Concerns and policy reactions, Oxford Scholarship Online 2012, p. 463, COM(2008)115 final, p. 4 en Raaijmakers \& Trommel 2005, par. 3.

12. Safe and sound: An EU approach to sovereign investment, bruegel.org, p. 6-8 en Chaisse 2012, p. 472-478.

13. J. de Kok, Towards a European framework for foreign investment reviews, European Law Review (24) 2019, p. 37. Zie SWD(2019)108 final voor een gedetailleerd overzicht van FDI in de EU en How Chinese companies facilitate technology transfer from the United States, uscc.gov voor een overzicht van China's strategieën.

14. Proposal for ensuring an improved level playing field in trade and investment, bmwi.de en European investment policy: A common approach to investment control, politico.eu.

15. $\operatorname{COM}(2017) 494$ final, p. 2.

16. $\operatorname{COM}(2017) 487$ final. De uitkomst van het onderzoek werd gelijk met de uiteindelijke Screeningverordening gepubliceerd, zie SWD(2019)108 final.

17. De verhouding tussen art. 207 VWEU en art. 4 VEU wordt niet behandeld in dit artikel.

18. Tenzij de vestigingsvrijheid (art. $49 \mathrm{VWEU}$ ) van toepassing is. 
spraak dat directe investeringen in de vorm van het verwerven en het houden van aandelen in kapitaalvennootschappen kapitaalverkeer zijn in de zin van artikel 63 VWEU. ${ }^{19}$ Bovendien kwalificeert een besluit tot het terugdraaien of blokkeren van FDI als een belemmering of beperking van het vrije verkeer van kapitaal. ${ }^{20}$

Een beperking van het vrije verkeer van kapitaal kan desondanks worden gerechtvaardigd op grond van de openbare orde of de nationale veiligheid (art. 65 lid 1 onder b VWEU). ${ }^{21}$ Deze begrippen hebben geen sluitende Europeesrechtelijke definitie. Lidstaten hebben, binnen de kaders gegeven door vaste rechtspraak van het Hof van Justitie van de Europese Unie (hierna: het Hof) en onder controle van instellingen van de EU, een beoordelingsmarge om hier invulling aan te geven. ${ }^{22}$ De openbare orde en nationale veiligheid kunnen enkel als grond voor een beperking dienen indien sprake is van een werkelijke en voldoende ernstige bedreiging die een fundamenteel belang van de samenleving aantast (of dreigt aan te tasten). ${ }^{23}$ Bovendien mogen deze gronden niet feitelijk voor zuiver economische doeleinden worden aangevoerd. ${ }^{24}$ Tevens moeten beperkingen (zoals screeningmechanismen) voldoende precies zijn, en moet worden voldaan aan de vier voorwaarden voor de belemmering van een fundamentele vrijheid. ${ }^{25}$ Dit houdt in dat een screeningmechanisme:

1. zonder discriminatie moet worden toegepast;

2. rechtvaardiging moet vinden in dwingende redenen van algemeen belang;

3. geschikt moet zijn om de verwezenlijking van het nagestreefde doel te waarborgen; en

4. niet verder moet gaan dan nodig is voor het bereiken van dat doel. ${ }^{26}$

De Screeningverordening rekt mogelijk de begrippen openbare orde en nationale veiligheid op door kritieke infrastruc-

19. Zie o.m. HvJ EU 21 oktober 2010, C-81/09, ECLI:EU:C:2010:622 (Idryma Typou), par. 48 en HvJ EU 17 september 2009, C-182/08, ECLI:EU:C:2009:559 (Glaxo Wellcome), par. 40.

20. HvJ EU 24 november 2016, C-464/14, ECLI:EU:C:2016:896 (SECIL), par. 45.

21. Of, in een geval waarin de vestigingsvrijheid in het geding is, art. 52 lid 1 VWEU.

22. De Commissie spreekt van een beoordelingsmarge die strikt moet worden opgevat, maar in de literatuur wordt tevens gesproken van een ruime beoordelingsmarge. Zie COM(2017)487 final, p. 4 en T.M. Stevens, Investeringstoets telecommunicatie, Ondernemingsrecht 2019/85, par. 2.

23. Zie o.m. HvJ EU 10 november 2011, C-212/09, ECLI:EU:C:2011:717 (Commissie/Portugal), par. 83 en HvJ EG 14 maart 2000, C-54/99, ECLI:EU:C:2000:124 (Eglise Scientology), par. 17.

24. Zie o.a. HvJ EU 22 oktober 2013, C-105/12-107/12, ECLI:EU:C: 2013:677, JOR 2013/334 m.nt. G.J. Vossestein (Nederland/Essent e.a.), par. 51 en HvJ EG 14 maart 2000, C-54/99, ECLI:EU:C:2000:124 (Eglise Scientology), par. 17.

25. HvJ EG 30 november 1995, C-55/94, ECLI:EU:C:1995:411 (Gebhard), par. 37 en C. Barnard \& S. Peers, European Union Law, Oxford: Oxford University Press 2017, p. 465-471.

26. HvJ EU 31 mei 2018, C-190/17, ECLI:EU:C:2018:357 (Zheng), par. 37, HvJ EU 7 juni 2012, C-39/11, ECLI:EU:C:2012:327, NJ 2012/481 m.nt. M.R. Mok (VBV - Vorsorgekasse), par. 29 en HvJ EG 13 juli 2000, C-423/98, ECLI:EU:C:2000:401 (Albore), par. 18-22. tuur en technologieën ruim te definiëren en onder de reikwijdte van de openbare orde en nationale veiligheid te brengen. ${ }^{27}$ Het is lastig te voorspellen waar het Hof de grens trekt tussen een grond die aangevoerd is voor zuiver economische doeleinden, wat verboden is, en een grond die aangevoerd wordt ter bescherming van kritieke infrastructuur om de openbare orde en nationale veiligheid te waarborgen. Niet uit te sluiten valt dat het Hof na het aannemen van de Screeningverordening minder snel zal oordelen dat deze grens overschreden is, waarmee de Screeningverordening mogelijk voor een ruimere uitleg van openbare orde en nationale veiligheid ten aanzien van derde landen kan zorgen.

Wanneer sprake is van verwerving van beslissende zeggenschap in een onderneming is enkel de vestigingsvrijheid (art. 49 VWEU) van toepassing. ${ }^{28}$ Investeerders uit derde landen kunnen echter geen beroep doen op de vestigingsvrijheid, waardoor FDI in een dergelijk geval eveneens teruggedraaid of geblokkeerd lijkt te kunnen worden voor andere redenen dan de openbare orde of nationale veiligheid indien de nationale wetgeving dit toestaat. Wanneer sprake is van een intra-EUinvestering, waardoor beslissende zeggenschap wordt verworven, zal de bescherming die voortvloeit uit de vestigingsvrijheid wel van toepassing zijn. Overigens moeten lidstaten met een screeningmechanisme voorzien in maatregelen om omzeiling van hun screeningmechanismen en -besluiten te voorkomen, waardoor mogelijk ook intra-EU-investeringen belemmerd kunnen worden die onder het vrije verkeer van kapitaal of de vestigingsvrijheid kunnen vallen. ${ }^{29}$ Een dergelijke maatregel doet echter geen afbreuk aan beide vrijheden, zo valt terug te lezen in de verordening. ${ }^{30}$ Wat deze verplichte maatregelen zouden kunnen zijn, wordt niet uitgewerkt, waardoor de Screeningverordening lidstaten geen sturing geeft over wat een acceptabele anti-omzeilingsmaatregel zou zijn.

De Screeningverordening laat de toepassing van Verordening (EG) 139/2004 (de 'Concentratieverordening') en de Unieregels inzake de prudentiële beoordeling van gekwalificeerde deelnemingen in de financiële sector onverlet. ${ }^{31}$ Bovendien moeten de (screeningmechanismen van) lidstaten onverkort voldoen aan internationale verdragen en handels- en

27. Aldus ook B.J. de Jong, C.D.J. Bulten \& E.J. Breukink, De conceptverordening voor screening van buitenlandse overnames en investeringen, Ondernemingsrecht 2018/18, afl. 2, par. 3 en W.M. Kros, De Verordening inzake screening van overnames in de EU - de gevolgen voor de M\&A praktijk, O\&F (27) 2019, afl. 3, p. 44-45. Nederland is een van de lidstaten die zorgen hebben uitgesproken over het verruimen van de openbare orde en nationale veiligheid, zie Kamerstukken II 2017/18, 22112, nr. 2437, p. 10.

28. Zie over de verhouding tussen art. 49 en art. 63 VWEU S.W. Schill, The European Union's foreign direct investment screening paradox: Tightening inward investment control to further external investment liberalization, Legal Issues of Economic Integration (46) 2019, afl. 2, p. 117-119 en De Kok 2019, p. 27-30.

29. Overweging 10 en art. 3 lid 6 Screeningverordening.

30. Overweging 10 Screeningverordening.

31. Overweging 36 en 37 Screeningverordening. 


\section{Maandblad}

Ondernemingsrecht

investeringsovereenkomsten. ${ }^{32}$ Een interessante vraag, die ik in dit artikel verder niet behandel, is in welke mate de Unierechtelijke en internationaalrechtelijke (kaders voor nationale) definities van openbare orde en nationale veiligheid gelijklopen.

\subsection{De Screeningverordening}

\subsubsection{Toepassingsgebied}

Alvorens in te gaan op de werking van de Screeningverordening, is het voor het toepassingsbereik van de Screeningverordening van belang om op enkele begrippen in te gaan. Zo is de Screeningverordening enkel van toepassing op investeringen die direct of indirect gedaan worden door buitenlandse (rechts)personen uit derde landen, en is deze niet van toepassing op investeringen zonder de intentie om invloed op het bestuur van en zeggenschap over de onderneming uit te oefenen ('portfolio-investeringen'). ${ }^{33}$

\subsubsection{Toetsingscriteria}

Om de toepassing van de Screeningverordening in goede banen te leiden bevat de verordening een niet-uitputtende lijst van toetsingscriteria die in aanmerking genomen kunnen worden bij de beoordeling of de gescreende FDI gevolgen kan hebben voor de openbare orde of nationale veiligheid. ${ }^{34} \mathrm{De}$ voor de toetsing benodigde informatie kan worden verzocht van partijen die bij de transactie betrokken zijn en dient verstrekt te worden aan de Commissie en de overige lidstaten. ${ }^{35}$ Voldoet een investeerder niet aan een informatieverzoek, dan zou dit in nationale screeningmechanismen gesanctioneerd kunnen worden middels het schorsen van zeggenschapsrechten of het blokkeren van de investering.

\subsubsection{Het samenwerkingsmechanisme}

De Screeningverordening voorziet in coördinatie en samenwerking in drie verschillende gevallen:

1. FDI onderworpen aan screening in de lidstaat van ontvangst; ${ }^{36}$

2. FDI die niet onderworpen wordt aan screening in de lidstaat van ontvangst; ${ }^{37}$ en

3. FDI met gevolgen voor projecten of programma's van Uniebelang. ${ }^{38}$

32. Zoals de bepalingen uit de algemene overeenkomst betreffende de handel in diensten (GATS) en multi- en bilaterale investeringsverdragen.

33. Overweging 9 en art. 2 onder 2 Screeningverordening. Hoe deze 'intentie' moet gaan worden getoetst, wordt niet beschreven.

34. Zie art. 4 Screeningverordening. Zo kan rekening worden gehouden met de mogelijke gevolgen van een investering voor kritieke infrastructuur en de eigendomsstructuur van een investeerder.

35. Art. 5, 6 en 9 Screeningverordening.

36. Art. 6 Screeningverordening.

37. Art. 7 Screeningverordening.

38. Zoals gedefinieerd in art. 8 Screeningverordening. De bijlage van de Screeningverordening bevat een indicatieve lijst van dergelijke projecten.
In geval 1 notificeert de ontvangende lidstaat de Commissie en andere lidstaten over de screening. ${ }^{39}$ De Commissie en niet-screenende lidstaten kunnen vervolgens advies uitbrengen aan de screenende lidstaat, mits zij over nuttige informatie beschikken of van oordeel zijn dat de gescreende investering gevolgen kan hebben voor de openbare orde en nationale veiligheid in meerdere lidstaten. Voor geval 2 voorziet de Screeningverordening in een soortgelijke procedure, waarbij opmerkingen en adviezen aan de lidstaat van ontvangst gestuurd kunnen worden. In zowel geval 1 als geval 2 kan een verzoek om aanvullende informatie door andere lidstaten of de Commissie worden gericht aan de lidstaat van ontvangst. ${ }^{40}$ De lidstaat van ontvangst moet 'terdege' rekening houden met de opmerkingen en adviezen. ${ }^{41}$ Voor geval 3 geldt een soortgelijke procedure, maar in dit geval moet 'zo veel mogelijk' rekening gehouden worden met een advies van de Commissie. ${ }^{42}$ Dit houdt in dat het afwijken van een advies van de Commissie gemotiveerd dient te worden. De Screeningverordening verschaft eveneens termijnen voor het bovenstaande. ${ }^{43}$ De screenende lidstaat blijft, ondanks de opmerkingen en adviezen, exclusief bevoegd een definitief screeningbesluit te nemen. ${ }^{44}$

Naast de bovenstaande samenwerking wordt ook op andere wijzen samengewerkt. Zo is in 2017 de deskundigengroep inzake de screening van buitenlandse directe investeringen in de EU opgericht ${ }^{45}$ en is internationale samenwerking met de bevoegde autoriteiten van derde landen mogelijk. ${ }^{46}$ Tot slot is van groot belang dat de lidstaten met een screeningmechanisme aan investeerders of betrokken ondernemingen de mogelijkheid bieden om tegen een screeningbesluit in beroep te gaan. $^{47}$

\subsubsection{Inwerkingtreding}

De Screeningverordening is op 10 april 2019 in werking getreden, maar is pas van toepassing met ingang van 11 oktober 2020. ${ }^{48}$ De Commissie heeft voor deze enigszins ongewone wijze van invoering gekozen om lidstaten voldoende tijd te geven (achttien maanden) om screeningmechanismen aan te

39. Waarbij de in art. 9 lid 2 Screeningverordening beschreven informatie dient te worden verstrekt.

40. Art. 6 lid 6 en art. 7 lid 5 Screeningverordening. Een dergelijk verzoek moet naar behoren gemotiveerd, beperkt tot de noodzakelijke informatie en proportioneel zijn. De screenende lidstaat moet deze informatie zonder onnodige vertraging verstrekken.

41. Art. 6 lid 9 en art. 7 lid 7 Screeningverordening.

42. Art. 8 lid 2 onder c Screeningverordening.

43. Art. 6 lid 6 en 7 en art. 7 lid 5 Screeningverordening. Een advies of opmerkingen dienen in beginsel binnen 35 kalenderdagen na ontvangst van een screeningnotificatie of aanvullende informatie te worden verstuurd.

44. Overweging 17 en 19 en art. 6 lid 9 Screeningverordening.

45. Art. 12 C(2017)7866 final. Deze groep deskundigen staat o.m. de Commissie bij met advies en deskundigheid.

46. Art. 13 Screeningverordening. De VS heeft een soortgelijke bepaling: 50 U.S.C. $\$ 4565(\mathrm{c})(3)$.

47. Art. 3 lid 5 Screeningverordening.

48. Art. 17 Screeningverordening. 
passen of in te voeren. ${ }^{49}$ Dit betekent echter niet dat investeringen verricht voor 11 oktober 2020 'vrij' plaats kunnen vinden: voor niet aan screening onderworpen investeringen kunnen lidstaten en de Commissie respectievelijk opmerkingen of een advies uitbrengen tot vijftien maanden na de desbetreffende investering. ${ }^{50}$ Er kunnen dus nog opmerkingen en adviezen worden uitgebracht op 11 oktober 2020 die zien op FDI van na 10 april 2019. ${ }^{51}$

\subsection{Kritiek op de Screeningverordening}

Hoewel de Screeningverordening mijns inziens een welkome stap is in de richting van een betere bescherming van vitale sectoren in de EU, is zij verre van perfect. Zo vindt geen harmonisatie van de begrippen openbare orde en nationale veiligheid plaats, waardoor investeerders geconfronteerd kunnen worden met potentieel 27 verschillende interpretaties. Dit is te verklaren in het licht van artikel 4 lid 2 VEU, maar het maakt het er voor investeerders niet voorspelbaarder op. Waar ligt immers de grens tussen een grond die wordt aangevoerd voor zuiver economische doeleinden en een grond die wordt aangevoerd ter bescherming van kritieke infrastructuur om de openbare orde en nationale veiligheid te waarborgen? En leidt de Screeningverordening tot een verruiming van deze begrippen (zie par. 2.2)?

De Screeningverordening geeft tevens slechts een zeer brede definitie van FDI. De lidstaten hebben, binnen de op zichzelf al onduidelijke kaders van de Screeningverordening, de ruimte om zelf (de reikwijdte en toetsingscriteria van) hun screeningmechanismen in te richten. Door het gebrek aan afbakening op Europees niveau zal voor een internationale transactie per relevante lidstaat moeten worden gekeken of sprake is van FDI die onder een screeningmechanisme valt. De Screeningverordening sluit voor de definitie van FDI aan bij het Hof, waarin het Hof uit lijkt te gaan van een functioneel criterium, maar ook deze is dusdanig breed dat zij geen duidelijkheid schept.

Het gebrek aan een duidelijkere afbakening van FDI zorgt ervoor dat onduidelijk is wanneer een zeggenschaps- en/of aandelenbelang groot genoeg zijn om van een daadwerkelijke deelname uit te mogen gaan in de zin van de Screeningverordening. ${ }^{52}$ Een andere vraag die men in dit kader kan stellen, is wanneer een verandering in de zeggenschapsverhouding (zonder een koop of uitgifte van aandelen) van een kapitaalvennootschap tot een kwalificatie als FDI leidt, en of

49. E. Monard, in: Jones Day Talks: EU's new foreign direct investment regulations eye specific sectors, YouTube 11 juni 2019.

50. Art. 7 lid 8 Screeningverordening.

51. Overweging 21 Screeningverordening.

52. De Jong, Bulten \& Breukink 2018, par. 3.1 en Kros 2019, p. 42-44. Het IMF en de OECD hanteren een ondergrens van $10 \%$ van de aandelen om van FDI te spreken, maar bij beursvennootschappen kan men mogelijk ook bij het verwerven van een klein pakket van de aandelen significante invloed uitoefenen op de besluitvorming. Het is immers niet voor niets dat substantiële deelnemingen van 3\% en $5 \%$ eveneens gemeld moeten worden bij de AFM (art. 5:38 Wft). sprake is van FDI bij verandering in de zeggenschap over een (buitenlandse) moedervennootschap of een buitenlandse vennootschap actief op de markt van een andere lidstaat. ${ }^{53}$ Een duidelijkere afbakening door het Hof of de Commissie is mijns inziens gewenst.

Het toepassingsgebied van de Screeningverordening is eveneens problematisch. De Screeningverordening is enkel van toepassing op investeringen van natuurlijke of rechtspersonen uit derde landen (extra-EU-investeringen). ${ }^{54}$ Dit werpt de vraag op in welke mate de Screeningverordening analoog van toepassing is op de screening van intra-EU-investeringen, temeer nu nationale screeningmechanismen momenteel veelal zien op zowel intra- als extra-EU-investeringen. ${ }^{55}$ De Screeningverordening laat immers expliciet de uitsluitende verantwoordelijkheid van lidstaten voor de eigen openbare orde en nationale veiligheid (art. 4 lid 2 VEU) onverlet, terwijl de screening van intra-EU-FDI mogelijk blijft onder artikel 65 lid 1 onder b VWEU. 56

Ondanks het bovenstaande valt wel voor te stellen waarom enkel investeringen door investeerders uit derde landen onder het toepassingsbereik van de Screeningverordening vallen: men wil niet dat iedere investering potentieel aan screening onderhavig is, waardoor de EU mogelijk haar investeringsvriendelijke reputatie kwijtraakt. Dit risico kan mijns inziens worden beperkt door juist met een verstrekkende Europese verordening te komen waarin duidelijkere eisen gesteld worden aan screeningmechanismen, waarbij strenge eisen aan het blokkeren of terugdraaien van investeringen worden gesteld.

Tot slot geeft de Screeningverordening weliswaar termijnen voor het verstrekken en verzoeken van informatie en het versturen van opmerkingen of adviezen, maar zij geeft geen maximumtermijn waarbinnen een screeningproces afgerond moet zijn. Het is dus goed mogelijk dat een screeningproces geruime tijd kan duren of voor onbepaalde tijd wordt aangehouden (al dan niet middels een verlenging van de screeningtermijn). ${ }^{57}$ Een onderzoek door een toezichthouder of ministerie naar de mogelijke gevaren van een transactie voor de openbare orde of nationale veiligheid kan zorgen voor negatieve publiciteit en onrust binnen het bedrijf, terwijl onzekerheid over het al dan

53. De Jong, Bulten \& Breukink 2018, par. 3.1.

54. Zie art. 2 lid 2 Screeningverordening voor de definitie van een buitenlandse investeerder.

55. Zo maken o.m. Duitsland (in geval van een sectorspecifieke screening), Nederland (in het wetsvoorstel ongewenste zeggenschap telecommunicatie) en Spanje geen onderscheid tussen investeerders van buiten of binnen de EU; zie voor een overzicht M. Levitt e.a., International comparative guide to foreign direct investment regimes 2020, Londen: Global Legal Group 2019.

56. Art. 1 lid 2 Screeningverordening. Bij de screening van intra-EU-investeringen kan tevens de vestigingsvrijheid ex art. 49 VWEU van toepassing zijn.

57. Zo kunnen screeningprocedures in o.m. Duitsland, Frankrijk, Nederland (in de voorgestelde wet ongewenste zeggenschap telecommunicatie) en Spanje zes maanden duren, zie Levitt e.a. 2019. 


\section{Maandblad \\ Ondernemingsrecht}

niet doorgaan van de transactie bij beursvennootschappen voor een lagere koers zou kunnen zorgen. ${ }^{58}$ Duurt een screening onredelijk lang, dan zullen investeerders in de praktijk afhaken voordat een finaal screeningbesluit is genomen. Zonder screeningbesluit zal men ook niet toekomen aan het instellen van een beroep tegen het screeningbesluit, waardoor de beroepsmogelijkheid (en daarmee de rechtsbescherming van investeerders) gedegradeerd wordt tot een wassen neus. Een maximumtermijn had daarom mijns inziens voor de hand gelegen.

\section{Screening van FDI in de Verenigde Staten}

\subsection{Achtergrond}

In de Verenigde Staten vindt de screening van investeringen plaats door de 'Committee on Foreign Investments in the United States' (CFIUS), onder het gezag van de president. CFIUS is in 1975 opgericht en bestaat voornamelijk uit de ministers van een aantal relevante ministeries en de hoofden van enkele overheidsinstellingen onder het voorzitterschap van de Minister van Financiën. ${ }^{59}$ De bevoegdheden van CFIUS zijn, vooral met het oog op Chinese pogingen (toegang tot) intellectueel eigendom te bemachtigen, ${ }^{60}$ recentelijk uitgebreid met de 'Foreign Investment Risk Review Modernization Act of 2018' (hierna: FIRRMA). ${ }^{61}$

Het Amerikaanse stelsel is, ondanks zijn tekortkomingen (zie par. 3.4 en 3.5), veel verder ontwikkeld dan het Europese stelsel. Het is daarom nuttig om te kijken hoe het Amerikaanse stelsel omgaat met de zaken die onder de Screeningverordening te beperkt of niet geregeld zijn.

\subsection{Toepassingsgebied}

CFIUS is verplicht om alle investeringen die als covered aangemerkt kunnen worden te onderzoeken. Een covered investering is ruim gedefinieerd als iedere fusie, acquisitie of overname die zou kunnen leiden tot buitenlandse controle van een Amerikaans bedrijf, ${ }^{62}$ ook als deze middels een joint venture plaatsvindt. ${ }^{63}$ Onderzocht wordt (1) of de (voorgenomen) investering de nationale veiligheid bedreigt, (2) of de investeerder gecontroleerd wordt door een buitenlandse mogendheid, en (3) of de investering resulteert in controle over kritie-

58. J.K. Jackson, The Committee on Foreign Investment in the United States (CFIUS), CRS report no. RL33388, Washington, DC: Congressional Research Service 2019 (online geraadpleegd op 1 september 2019), p. 16-17.

59. 50 U.S.C. $\$ 4565(\mathrm{k})(2)$. O.m. de Secretary of the Treasury, de Secretary of Homeland Security, de Secretary of Energy en de Attorney General.

60. Zie voor een overzicht van China's strategieën: How Chinese companies facilitate technology transfer from the United States, uscc.gov.

61. Foreign Investment Risk Review Modernization Act of 2018 ('FIRRMA'), Subtitle A of Title XVII of P.L. 115-232, Stat. 2173.

62. Een onderneming is Amerikaans indien zij kwalificeert als 'a person engaged in interstate commerce in the United States' (50 U.S.C. $\$$ 4565(a)(13)). Buitenlandse controle is een functioneel criterium, zie Jackson 2019, p. 26-27.

63. 50 U.S.C. $\$ 4565(\mathrm{a})(4)(\mathrm{B})(\mathrm{i})$. ke infrastructuur waardoor de nationale veiligheid bedreigd kan worden. ${ }^{64}$

Het begrip covered investering is sterk uitgebreid door FIRRMA, waardoor nu tevens bepaalde typen vastgoedtransacties en veranderingen in de zeggenschapsrechten van een buitenlandse (rechts)persoon met betrekking tot een Amerikaans bedrijf onder toezicht van CFIUS staan. ${ }^{65}$ Dit geldt eveneens voor investeringen met betrekking tot kritieke infrastructuur $^{66}$ en technologieën, ${ }^{67}$ en investeringen waardoor een buitenlandse investeerder toegang krijgt tot bepaalde technische informatie of gevoelige persoonsgegevens. ${ }^{68}$ Vergelijkbaar met de Screeningverordening voorziet FIRRMA ook in een mogelijkheid om iedere investering, overdracht, overeenkomst of andersoortige constructie te onderzoeken die het ontwijken van CFIUS-jurisdictie als doel heeft. ${ }^{69}$ De Amerikaanse regelgeving heeft een ruim toepassingsgebied, maar bevat tevens enkele uitgezonderde typen investeringen (waaronder 'greenfield' - en portfolio-investeringen). ${ }^{70}$

\subsection{De procedure}

CFIUS is bevoegd om een screening te verrichten indien sprake is van een covered investering. De procedure van CFIUS volgt een getrapt systeem, bestaand uit een informele fase en drie formele fasen. De informele fase kent geen termijnen en vangt aan op verzoek van de investeerder. ${ }^{71}$ CFIUS heeft in de informele fase de tijd om de potentiële knelpunten te adresseren, en kan bovendien vroegtijdig aangeven hoe de investering gestructureerd moet worden om risico's voor de nationale veiligheid te mitigeren. Door ervoor te kiezen de informele fase te doorlopen voorkomen investeerders mogelijk een duurder, intensiever en meer publiek formeel onderzoek. ${ }^{72}$

De Formal Review-fase vangt aan na een melding van een van de bij de investering betrokken partijen of op initiatief van CFIUS. ${ }^{73}$ De melding is niet altijd vrijwillig. Betrokken partijen zijn verplicht een voorgenomen investering te melden wanneer (1) sprake is van een covered investering, (2) een buitenlandse mogendheid een (in)direct substantieel belang heeft in de buitenlandse investeerder, en (3) het Amerikaanse bedrijf actief is met betrekking tot kritieke technologie of

64. 50 U.S.C. $\$ 4565$ (b)(2)(B).

65. 50 U.S.C. $\$ 4565(\mathrm{a})(4)(B)(i i), 50$ U.S.C. $\$ 4565(\mathrm{a})(4)(\mathrm{D})$ en Jackson 2019, p. $20-21$.

66. 50 U.S.C. $\$ 4565(a)(5)$. Zie Jackson 2019, p. 25 voor een overzicht.

67. Kritieke technologieën, gedefinieerd in 50 U.S.C. $\$ 4565(\mathrm{a})(6)$, zijn o.m. technologieën gerelateerd aan wapens, nucleaire energie en bepaalde gifstoffen.

68. 50 U.S.C. $\$ 4565(\mathrm{a})(4)(\mathrm{D})$ en 50 U.S.C. $\$ 4565(\mathrm{a})(4)(\mathrm{B})(\mathrm{iii})(\mathrm{III})$. De term gevoelige persoonsgegevens wordt niet verder uitgewerkt.

69. 50 U.S.C. $\$ 4565(\mathrm{a})(4)(\mathrm{B})(\mathrm{v})$.

70. 31 CFR $\$ 800.302$ (b) en Jackson 2019, p. 24. Met 'greenfield'-investeringen doel ik hier op het creëren van een nieuwe vennootschap.

71. Jackson 2019, p. 16-17 en Bulten e.a. 2017, p. 184-185.

72. Partijen zullen bij een formeel CFIUS-onderzoek $1 \%$ van de waarde van de investering moeten betalen als 'filing fee', met een maximum van USD 300.000. Zie 50 U.S.C. $\$ 4565(\mathrm{p})(3)$.

73. 50 U.S.C. $\$ 4565(\mathrm{~b})(1)(\mathrm{C}-\mathrm{D})$. 
infrastructuur. ${ }^{74}$ Voor partijen met een minder groot risicoprofiel is het mogelijk een Short Form-procedure te doorlopen. Deze procedure bestaat uit het overleggen van een korte melding (maximaal vijf pagina's) waarin relevante informatie is opgenomen. ${ }^{75}$ CFIUS heeft vervolgens 30 dagen om op deze melding te reageren, waarna de investering goedgekeurd wordt of de partijen alsnog kunnen overgaan tot een volledige melding, of CFIUS zelf een onderzoek start. ${ }^{76}$ Binnen 30 dagen na de melding beslist CFIUS of zij goedkeuring verleent aan de investering.

Wordt deze goedkeuring niet verleend, dan gaat een tweede termijn van 45 dagen lopen waarin CFIUS overgaat tot een National Security Review (hierna: NSR). In deze fase kijkt CFIUS of de investering mogelijk een bedreiging voor de nationale veiligheid vormt. De NSR bestaat tevens uit een onderzoek van de Director of National Intelligence, die een grondige analyse uitvoert naar de risico's voor de nationale veiligheid. De betrokken partijen kunnen overigens op ieder moment de melding intrekken (mits deze vrijwillig was) en op een later moment opnieuw melding doen bij CFIUS. ${ }^{77}$ Als uit de NSR blijkt dat (1) de investering mogelijk een gevaar vormt voor de nationale veiligheid, (2) de buitenlandse investeerder gecontroleerd wordt door een buitenlandse mogendheid, en/ of (3) de investering leidt tot buitenlandse controle van kritieke infrastructuur, dan volgt een National Security Investigation (hierna: NSI), waarin meer onderzoek naar de investering wordt gedaan. ${ }^{78}$ Deze fase duurt 45 dagen, maar kan onder bijzondere omstandigheden worden verlengd. ${ }^{79}$ Gedurende de NSR en NSI wordt door de Minister van Financiën een lead agency aangewezen, die het voortouw neemt in het onderzoek en de daarbij relevante uitvoerende taken.

Aan het einde van of tijdens een NSR en NSI geeft CFIUS een verklaring van geen bezwaar af, stelt zij nadere eisen aan de investering of geeft zij de president een aanbeveling de investering te blokkeren. ${ }^{80}$ De president heeft na een aanbeveling 15 dagen om te besluiten of de investering geschorst of geblokkeerd moet worden. ${ }^{81}$ Dit mag enkel wanneer de president tot de conclusie komt dat (1) er geloofwaardig bewijs is dat de investering de nationale veiligheid in gevaar dreigt te brengen en (2) er geen andere regelgeving is op grond waarvan dit risico geadresseerd kan worden, ${ }^{82}$ rekening houdend met enkele voorgeschreven factoren. ${ }^{83}$ Tegen een besluit van de president staat geen rechtsmiddel open (zie par. 3.5).${ }^{84}$ Overigens is de president niet de enige die actie kan ondernemen: CFIUS kan

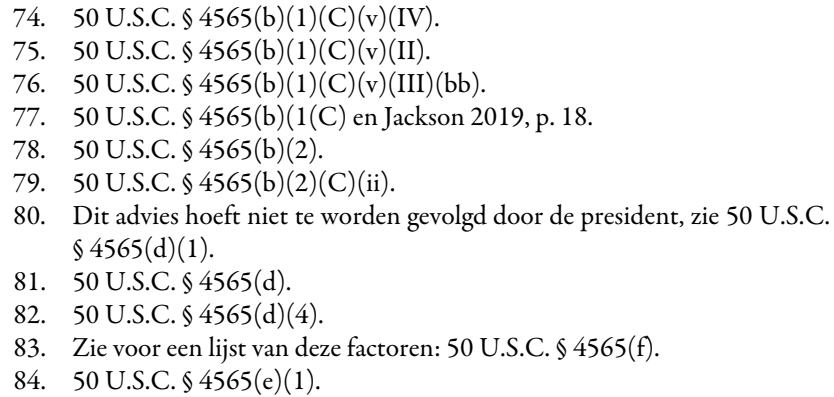

tijdens de NSR en NSI de potentiële risico's voor de nationale veiligheid tijdelijk mitigeren door een investering te schor$\operatorname{sen}^{85}$ en 'negotiate, enter into or impose, and enforce any agreement or condition with any party to the covered transaction in order to mitigate any risk to the national security of the United States that arises as a result of the covered transaction' ${ }^{86}$ CFIUS beschikt daarmee over een ruim palet aan bevoegdheden.

Het Amerikaanse stelsel heeft, anders dan zijn Europese evenknie (zie par. 2.4), een uiterlijke termijn voor de screening van investeringen. Er zijn ook andere elementen die in het Europese stelsel niet zouden misstaan. Zo zal de rechtszekerheid voor buitenlandse investeerders verbeteren indien ook de Europese screeningmechanismen in een informele fase en een Short Form-procedure voorzien. ${ }^{87}$ Screenende lidstaten zijn dan (nog) niet gebonden aan de termijnen uit de Screeningverordening en toepasselijke nationale screeningmechanismen, wat de administratieve druk voor de desbetreffende lidstaten kan verlichten. Ook zijn de zorgen over voorgenomen investeringen dan reeds in het voortraject bekend. Dit laatste is voordelig voor zowel de lidstaat als de investeerder: de lidstaat verkrijgt invloed op het structureren van de investering, terwijl de investeerder de gewenste rechtszekerheid krijgt. Dit zal in mindere mate het geval zijn indien een nationaal screeningmechanisme het toestaat om, eventueel naar aanleiding van opmerkingen van andere lidstaten of een advies van de Commissie, het onderzoek te heropenen en opnieuw te screenen. Dit is in het Amerikaanse stelsel na het verlopen van de termijnen of een verklaring van geen bezwaar in beginsel niet meer mogelijk; de Screeningverordening zwijgt hierover. ${ }^{88}$ Onder de Screeningverordening kunnen de Commissie en de lidstaten tot vijftien maanden na een transactie opmerkingen of een advies indienen waarmee 'terdege' of 'zo veel mogelijk' rekening gehouden dient te worden. Het is onduidelijk wat dient te gebeuren met deze opmerkingen en adviezen na een definitief screeningbesluit. ${ }^{89}$ Het lijkt mij wenselijk dat lidstaten enkel van screeningbesluiten terug kunnen komen indien sprake is van wezenlijke nieuwe informatie of ontwikkelingen.

\subsection{Toetsingscriteria}

Net als de Screeningverordening bevat ook de Amerikaanse regelgeving een niet-uitputtende lijst van factoren die gewogen moeten worden door de president en CFIUS bij een screening. ${ }^{90}$ Hoewel deze factoren grofweg overeenkomen met de factoren uit de Screeningverordening, zijn er ook opvallende verschillen. Zo moeten de president en CFIUS rekening

\footnotetext{
85. 50 U.S.C. $\$ 4565(1)(1)$.

86. 50 U.S.C. $\$ 4565(\mathrm{l})(3)(\mathrm{A})(\mathrm{i})$.

87. In sommige lidstaten, waaronder Duitsland, Finland, Oostenrijk en Spanje, is het reeds mogelijk voorafgaand aan een investering in gesprek met de screenende autoriteiten te treden omtrent de toelaatbaarheid van de investering, zie Levitt e.a. 2019.

88. 31 CFR $\$ 800.601$.

89. Aldus ook Kros 2019, p. 55-56.

90. 50 U.S.C. $\$ 4565(f)$ en FIRRMA $\$ 1702(c)$.
} 


\section{Maandblad}

Ondernemingsrecht

houden met het potentiële effect van een investering op 'US technological leadership in areas affecting U.S. national security', en moet extra rekening gehouden worden met landen van 'special concern'. ${ }^{91}$ Een investeerder uit een risicoland kan dus rekenen op extra aandacht van CFIUS. Ook is er aandacht voor mogelijke cybersecurityrisico's, het prijsgeven van persoonsgegevens van Amerikaanse burgers, de veiligheid van persoonsgegevens, en of de investeerder zich in het verleden aan de wet heeft gehouden.

Net als in de Screeningverordening is het begrip 'national security' in de Amerikaanse wetgeving niet gedefinieerd. National security dient in het kader van CFIUS te worden 'construed so as to include those issues relating to "homeland security", including its application to critical infrastructure'. ${ }^{92}$ Ieder van de deelnemende ministeries en overheidsinstellingen die lid zijn van CFIUS hanteert een eigen definitie die is toegespitst op het mandaat van het desbetreffende lid. ${ }^{93}$ Markant is dat eind jaren tachtig juist werd tegengehouden dat de president investeringen kon blokkeren indien deze investeringen een bedreiging vormden voor 'essential commerce'. Een uitbreiding waardoor ook met economische factoren rekening kon worden gehouden, werd niet wenselijk geacht. ${ }^{94}$ Deze terughoudendheid is anno 2020 niet meer herkenbaar. In de meest recente National Security Strategy (2017) staat prominent: 'Economic security is national security.' ${ }^{\prime} 5$ Deze visie uit zich ook in beleid. Zo werden begin 2018 importtarieven opgelegd op staal en aluminium, waarbij de nationale veiligheid werd aangevoerd als reden. ${ }^{96}$ De redenering was onder meer dat de Amerikaanse staal- en aluminiumindustrieën door overproductie geschaad worden, wat een gevaar voor de nationale veiligheid zou opleveren. ${ }^{97}$ Op dezelfde grond dreigt president Trump met Amerikaanse importtarieven op buitenlandse auto's en auto-onderdelen. Een sterke(re) Amerikaanse autoindustrie zou essentieel zijn voor de nationale veiligheid. ${ }^{98}$ Het

91. Gedefinieerd in FIRRMA $\$ 1702(\mathrm{C})(1)$ als een land 'that has a demonstrated or declared strategic goal of acquiring a type of critical technology or critical infrastructure that would affect United States leadership in areas related to national security'.

92. 50 U.S.C. $\$ 4565(\mathrm{a})(1)$.

93. Jackson 2019, p. 13.

94. Jackson 2019, p. 7-8 en M. Greidinger, The Exon-Florio Amendment: A solution in search of a problem, American University International Law Review (6) 1991, afl. 2, p. 128-132.

95. United States (White House Office), National security strategy of the United States of America, december 2017, p. 17.

96. Op grond van 19 U.S.C. $\$ 1862$ kan de president importtarieven opleggen indien goederen worden geïmporteerd naar de VS onder omstandigheden of in kwantiteiten waardoor de nationale veiligheid bedreigd wordt.

97. President Donald J. Trump is addressing unfair trade practices that threaten to harm our national security, whitehouse.gov en W.H. Weber $\&$ R. Baisch, Revisiting the public moral/order and the security exception under the Gats, Asian Journal of WTO and International Health Law and Policy (13) 2018, afl. 2, p. 377-378.

98. Adjusting imports of automobiles and automobile parts into the United States, whitehouse.gov. gevoel beklijft dat de grens tussen nationale veiligheid en protectionisme inmiddels sterk vervaagd is. ${ }^{99}$

Zoals eerder aangegeven (zie par. 2.2) geeft het Unierecht slechts kaders waarbinnen lidstaten zelf bepalen wat tot de openbare orde en nationale veiligheid behoort. Dit kader is weliswaar niet sterk afgebakend, maar het waakt wel degelijk voor misbruik van de begrippen voor zuiver economische doeleinden of andersoortig onzuiver gebruik. Het Amerikaanse stelsel biedt mijns inziens ten aanzien van deze begrippen geen model om in de EU na te streven.

\subsection{Transparantie en rechtsbescherming}

Het screeningproces dat CFIUS hanteert, is slechts beperkt transparant. Enkele gespecificeerde leden van het Congres worden over afgeronde screenings ingelicht, ${ }^{100}$ en het Congres ontvangt eens per jaar een jaarverslag van CFIUS. ${ }^{101}$ Voor de investeerders en hun wederpartij(en) is het proces verre van transparant: zij hebben enkel een recht om inzicht te krijgen in en te reageren op de niet-vertrouwelijke gronden voor het opleggen van maatregelen door CFIUS en het blokkeren of terugdraaien van een investering door de president. ${ }^{102}$ Vertrouwelijke informatie, waaronder mogelijk de gronden voor het blokkeren of terugdraaien van een investering, wordt niet gedeeld. ${ }^{103}$ De transparantie voor investeerders is daarmee zeer beperkt, temeer omdat de leden van CFIUS en de president bepalen wat vertrouwelijk is. ${ }^{104}$

Tegen de beslissingen van de president is geen beroep mogelijk, ${ }^{105}$ tenzij een beroep ziet op een mogelijke schending van de Grondwet in het besluitvormingsproces. ${ }^{106}$ Slechts een enkele keer is een beroep ingesteld tegen maatregelen van CFIUS en een presidentiële beslissing. Helaas werd deze zaak, Ralls Corp. $v$ CFIUS, geschikt voordat een rechter zich kon uitlaten over de rechtsgeldigheid van de maatregelen die CFIUS had opgelegd (waaronder het schorsen van de transactie). ${ }^{107}$

99. Aldus ook Bulten e.a. 2017, p. 188 en P. Connel \& T. Huang, An empirical analysis of CFIUS: Examining foreign investment regulation in the United States, Yale Journal of International Law (39) 2014, p. 132-133.

100. 50 U.S.C. $\$ 4565$ (b)(3). Dit kan ook op grond van 50 U.S.C. $\$ 4565$ (g) op verzoek van gespecificeerde leden van het Congres.

101. 50 U.S.C. $\$ 4565(\mathrm{~m})$. Een gedeclassificeerde versie dient ieder jaar te worden gepubliceerd. CFIUS heeft dit, sinds de publicatie van het jaarverslag van 2015 , niet meer gedaan.

102. Ralls Corporation v Committee on Foreign Investment in the United States, 758 F.3d 296, District of Columbia Circuit 2014 (hierna: Ralls Corp. v CFIUS), p. 319-320 en Bulten e.a. 2017, p. 183.

103. A.W. Salladin \& A.J. Schmidt, CFIUS post-Ralls: Ramifications for sovereign wealth funds, International Review of Law 2015, afl. 2, p. $15-16$.

104. Exec. Order No. 13526, 75 Fed. Reg. 707 (5 januari 2010).

105. 50 U.S.C. $\$ 4565(\mathrm{e})(1)$.

106. Voor zover sprake is van een schending van 'due process', zie Ralls Corp. v CFIUS, p. 308-312 en Jackson 2019, p. 19-20.

107. Zie J. Wang, Ralls Corp v. CFIUS: A new look at foreign direct investment to the US, Columbia Journal of Transnational Law (54) 2016, afl. 3, p. 54-55. 
De onmogelijkheid om tegen definitieve screeningbesluiten op te komen zou in de EU niet alleen in strijd zijn met artikel 3 lid 5 van de Screeningverordening, maar tevens met vaste rechtspraak van het Hof. ${ }^{108}$ De Amerikaanse aanpak zou daarom niet zijn toegestaan in de EU. De problematiek uit Ralls Corp. v CFIUS is daarentegen wel degelijk relevant voor de EU. Hoe zullen de verschillende lidstaten bijvoorbeeld omgaan met de kwalificatie van vertrouwelijk materiaal? En in hoeverre zullen de gronden voor een screeningbesluit hieronder vallen? Zijn de lidstaten altijd verplicht om in detail de gronden voor een screeningbesluit toe te lichten? Het is denkbaar dat de openbare orde en nationale veiligheid gediend zijn bij de vertrouwelijkheid van de gronden voor een screeningbesluit, maar dit staat op gespannen voet met de effectiviteit van de beroepsmogelijkheden van investeerders: onbekende gronden zijn per slot van rekening lastig aan te vechten.

\section{Europa, quo vadis?}

\subsection{Impact Screeningverordening}

Het is mijns inziens positief dat eindelijk een eerste (weliswaar voorzichtige) stap gemaakt is om het sterk gefragmenteerde landschap van screeningmechanismen omwille van de openbare orde en nationale veiligheid te harmoniseren. Door het uitwisselen van informatie en de jaarlijkse verslaggeving door de lidstaten ${ }^{109}$ wordt meer zicht gecreëerd op FDI in de EU, wat de kwaliteit van de screeningbesluiten en eventuele latere (Unierechtelijke) regulering ten goede zal komen. ${ }^{110}$ Dat neemt niet weg dat de Screeningverordening een politiek compromis is dat slechts beperkt bijdraagt aan een transparanter en meer voorspelbaar regulatoir landschap voor investeerders.

Verschillende lidstaten zullen hun wetgeving moeten aanpassen om aan het samenwerkingsmechanisme uit de Screeningverordening te voldoen. ${ }^{111}$ Door deze wijzigingen kunnen screeningprocedures mogelijk langer duren, aangezien een screenende lidstaat FDI moet notificeren en rekening moet kunnen houden met opmerkingen van andere lidstaten en adviezen van de Commissie (zie par. 2.3.3 ${ }^{112}$ Daar komt bij dat de Commissie recentelijk de druk op de lidstaten heeft opgevoerd om screeningmechanismen in te voeren en bestaande screeningmechanismen aan te scherpen vanwege het uitbreken van de COVID-19-pandemie. De Commissie wijst hierbij op de risico's van pogingen tot het verwerven van gezond-

108. Zie o.m. HvJ EU 28 maart 2017, C-72/15, ECLI:EU:C:2017:236 (Rosneft), par. 73 en HvJ EU 18 december 2014, C-552/13, ECLI:EU:C:2014:2453 (Abdida), par. 45

109. Art. 5 Screeningverordening.

110. Aldus ook De Kok 2019, p. 41

111. Zo zullen in Nederland de Elektriciteitswet 1998, de Gaswet en het wetsvoorstel ongewenste zeggenschap telecommunicatie moeten worden gewijzigd, zie Kros 2019, p. 53.

112. Aldus ook Kros 2019, p. 54-55. De Commissie verwacht dat een screeningprocedure normaal gesproken 35 dagen duurt, zie Screening of foreign direct investment - An EU framework, trade.ec.europa.eu. heidszorgcapaciteiten of investeringen in aanverwante bedrijfstakken zoals farmaceutische industrie. ${ }^{113}$

Voor de praktijk is het jammer dat de rechtszekerheid voor bij FDI betrokken partijen niet of slechts in beperkte mate is toegenomen door de Screeningverordening (zie par. 2.4). Partijen hebben nog steeds te maken met verschillende screeningmechanismen, waarbij er per lidstaat onder meer verschillen kunnen zijn voor de invulling van begrippen zoals de openbare orde, nationale veiligheid en FDI. De Unierechtelijke kaders voor deze begrippen zijn evenmin duidelijk. Bovendien werken screeningmechanismen mogelijk met verschillende termijnen en anti-omzeilingsmaatregelen.

Een goede voorbereiding voor een voorgenomen transactie is daarom essentieel om verminderd risico te lopen op het blokkeren of terugdraaien van een investering door de nationale autoriteiten. Daarbij dient men bij een voorgenomen investering mijns inziens in te gaan op de volgende vragen:

a. Valt de voorgenomen investering binnen het toepassingsbereik van een screeningmechanisme? Zo ja, in welke lidstaten?

b. Wordt de investering gedaan in een vitale of anderszins gevoelige sector?

c. Is sprake van (in)directe betrokkenheid van een buitenlandse overheid of andere factoren, waardoor de investeerder op extra aandacht mag rekenen van de nationale autoriteiten?

\subsection{Gaan we richting een Europese CFIUS?}

Het valt lastig te voorspellen welke ontwikkelingen screeningmechanismen in de EU en het Unierechtelijke kader de komende jaren door gaan maken. De doeltreffendheid en het functioneren van de Screeningverordening zullen uiterlijk 12 oktober worden getoetst door de Commissie, waarna men zal discussiëren over mogelijke wijzigingen in het Unierechtelijke kader. ${ }^{114}$

In de literatuur wordt met enige regelmaat een mogelijke screeningbevoegdheid van de Commissie besproken, vaak met verwijzing naar CFIUS. ${ }^{115}$ Hierin zijn twee varianten denkbaar: (1) exclusieve screening door de Commissie of (2) screening door zowel de lidstaten als de Commissie. Het is onwaarschijnlijk dat toekomstige wetgeving de screening van

113. Richtsnoeren voor de lidstaten betreffende buitenlandse directe investeringen en vrij verkeer van kapitaal uit derde landen en de bescherming van de strategische activa van Europa, in afwachting van de toepassing van Verordening (EU) 2019/452 (PbEU 2020, C 99 I/01). Zie hierover tevens COVID-19 and FDI screening: EU Commission increases pressure on member states to set up screening mechanisms, akd.eu.

114. Art. 15 Screeningverordening. Nadien zullen de doeltreffendheid en het functioneren van de Screeningverordening eens in de vijf jaar worden getoetst.

115. Zie o.m. De Kok 2019, p. 46-47, N. Lavranos, Enkele kritische kanttekeningen bij het EU-voorstel voor de screening van buitenlandse directe investeringen in de Europese Unie, SEW, Tijdschrift voor Europees en economisch recht 2018/133, afl. 9, p. 363-364 en Di Benedetto 2017, p. $26-28$. 


\section{Maandblad \\ Ondernemingsrecht}

FDI volledig zal overlaten aan de Commissie. Behalve dat dit waarschijnlijk politiek niet haalbaar is - de huidige Screeningverordening is immers het gevolg van een politiek compromis en is na de conceptverordening afgezwakt -, zou het strijdig zijn met de exclusieve bevoegdheid van lidstaten ten aanzien van de nationale veiligheid (art. 4 lid 2 VEU). Voor het volledig overhevelen van screeningbevoegdheid van de lidstaten naar de Commissie zou daarom een verdragswijziging vereist zijn, wat mij niet waarschijnlijk lijkt.

Variant 2 was in het concept van de Screeningverordening opgenomen, maar lijkt eveneens niet haalbaar. Volgens artikel 3 lid 2 en artikel 9 van deze conceptverordening zou de Commissie bevoegd zijn FDI te screenen die waarschijnlijk gevolgen heeft voor projecten of programma's van Uniebelang, maar deze bevoegdheid heeft de uiteindelijke Screeningverordening niet gehaald. ${ }^{116}$ Door Di Benedetto is betoogd dat de screeningbevoegdheid van de Commissie de exclusieve bevoegdheid van lidstaten ten aanzien van de nationale veiligheid en openbare orde onverlet laat: de lidstaten blijven immers screeningbevoegd en zijn vrij in het uitoefenen van hun bevoegdheden. ${ }^{117}$ Een dergelijke restrictieve lezing van artikel 4 lid 2 VEU miskent dat er een (gedeeltelijke) overlap is tussen de openbare orde en nationale veiligheid van de EU en die van de individuele lidstaten. De bevoegdheden van de lidstaten zouden in een dergelijke situatie niet exclusief zijn, waardoor een screeningbevoegdheid van de Commissie strijdig zou zijn met artikel 4 lid 2 VEU. ${ }^{118}$

De Screeningverordening is mijns inziens geen eerste stap richting een Europese CFIUS. Een toepassing van het Amerikaanse stelsel zou tegen Europeesrechtelijke bezwaren aanlopen (zie par. 3.4 en 3.5 ), en bovendien verdragswijzigingen vereisen. De Screeningverordening valt wel te zien als een voorzichtige stap richting meer invloed en toezicht vanuit de EU op investeringsscreening in de verschillende lidstaten, aangezien de Commissie door het samenwerkingsmechanisme en het uitbrengen van adviezen nauwer betrokken raakt bij investeringsscreening door de verschillende lidstaten.

\section{Conclusie}

Het is positief dat een eerste stap is gemaakt om het gefragmenteerde landschap van nationale screeningmechanismen enigszins te harmoniseren. Een samenwerking tussen de Commissie en de verschillende lidstaten is eveneens welkom, aangezien dit waarschijnlijk zal leiden tot een betere inschatting van en reactie op de risico's van FDI in de EU. Daartegenover staat dat de Screeningverordening de bestaande onzekerheid bij investeerders helaas niet zal kunnen wegnemen. $\mathrm{Zij}$ zullen nog steeds afhankelijk zijn van nationale screeningmechanismen, die onder meer verschillen in toepassingsgebied, termijnen en toetsingscriteria, terwijl de Unierechtelijke kaders waarbinnen de lidstaten hun screeningmechanisme dienen in te richten geenszins duidelijk zijn.

De Screeningverordening lijkt kortom geen stap in de richting van een Europese CFIUS. Momenteel lijkt een dergelijke europeanisering van de screeningbevoegdheden politiek niet haalbaar, mede doordat dit verdragswijzigingen zou vereisen. Het voorgaande neemt niet weg dat de lidstaten en de Commissie het Unie- en nationaalrechtelijke kader kunnen verbeteren door te kijken naar de screening van investeringen door CFIUS in de Verenigde Staten. Een uiterlijke termijn en een Short Form-achtige procedure bij nationale screeningmechanismen lijken mij wenselijke aanvullingen.

Tot slot zal men in de M\&A-praktijk een scherp beeld moeten hebben van eventuele toepasselijke screeningmechanismen om niet het risico te lopen dat een transactie door de nationale autoriteiten wordt geblokkeerd of teruggedraaid. Voor de praktijk zal de Screeningverordening weinig houvast bieden. 